Journal of Applied Pharmaceutical Science Vol. 7 (05), pp. 061-065, May, 2017

Available online at http://www.japsonline.com

DOI: $10.7324 / \mathrm{JAPS} .2017 .70511$

ISSN 2231-3354 (cc) BY-NC-SA

\title{
Chemical Constituents of Hoya cagayanensis C. M. Burton
}

\author{
Consolacion Y. Ragasa ${ }^{1,2^{*}}$, Melissa S. Borlagdan ${ }^{1,3}$, Fernando B. Aurigue $^{4}$, Robert Brkljača ${ }^{5}$, Sylvia Urban ${ }^{5}$ \\ ${ }^{1}$ Chemistry Department, De La Salle University, 2401 Taft Avenue, Manila 1004, Philippines. ${ }^{2}$ Chemistry Department, De La Salle University Science \& \\ Technology Complex Leandro V. Locsin Campus, Biñan City, Laguna 4024, Philippines. ${ }^{3}$ Food and Nutrition Research Institute- Department of Science \\ and Technology, Bicutan, Taguig, Metro Manila, Philippines. ${ }^{4}$ Agriculture Research Section, Atomic Research Division, Philippine Nuclear Research \\ Institute-Department of Science and Technology, Commonwealth Avenue, Diliman, Quezon City 1101, Philippines. ${ }^{5}$ School of Science (Discipline of \\ Applied Chemistry and Environmental Science), RMIT University (City Campus), Melbourne 3001, Victoria, Australia.
}

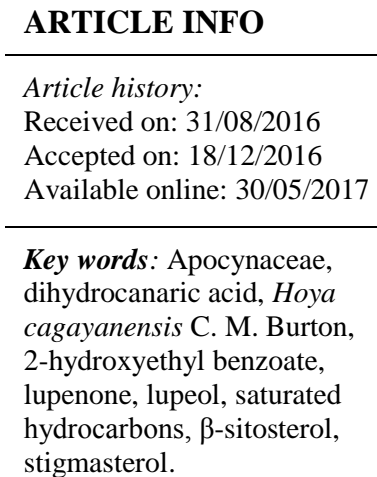

\section{INTRODUCTION}

Hoya is a genus of flowering plants in the family Apocynaceae. Most are epiphytic vines with succulent leaves and attractive clusters of flowers. There are at least 109 species of Hoya found in the Philippines, 88 of these are endemic to the country (Aurigue, 2013). Among them is Hoya cagayanensis C. M. Burton, first discovered in Cagayan province but also collected from Laguna and Quezon provinces in Luzon island, Philippines. It has become popular as an ornamental plant among collectors in the country and also abroad due to its spice-scented flowers, lush foliage, and ease of culture. No report on their ethnobotany or chemical analysis have been found. This study is part of our research on the chemical constituents of Philippine endemic and indigenous hoyas. We earlier reported the isolation

\footnotetext{
* Corresponding Author

Email: consolacion.ragasa@dlsu.edu.ph
}

of lupenone and lupeol from the roots; lupeol, squalene and $\beta$ sitosterol from the leaves; and betulin from the stems of $H$. mindorensis Schlechter (Ebajo et al., 2014). In another study, we reported the isolation of lupeol, $\alpha$-amyrin, $\beta$-amyrin, lupeol acetate, $\alpha$-amyrin acetate, and $\beta$-amyrin acetate from the stems; and $\alpha$-amyrin, bauerenol, squalene, lutein, $\beta$-sitosterol, and stigmasterol from the leaves of $H$. multiflora Blume (Ebajo et al., 2015a). The isolation of $\beta$-amyrin cinnamate and taraxerol from the stems; and taraxerol, triglycerides, chlorophyll a, and a mixture of $\beta$-sitosterol and stigmasterol from the leaves of $\mathrm{H}$. wayetii Kloppenb. has been reported (Ebajo et al., 2015b). Furthermore, the isolation of taraxerol, taraxerone, a mixture of $\beta$-sitosterol and stigmasterol, and a mixture of $\alpha$-amyrin cinnamate and $\beta$-amyrin cinnamate from the stems; taraxerol, taraxerone, and $\beta$-sitosterol from the roots; a mixture of $\alpha$-amyrin cinnamate and $\beta$-amyrin cinnamate from the flowers; and squalene, $\beta$-sitosterol, and saturated hydrocarbons from the leaves of $H$. buotii has been reported (Ebajo et al., 2015c). 

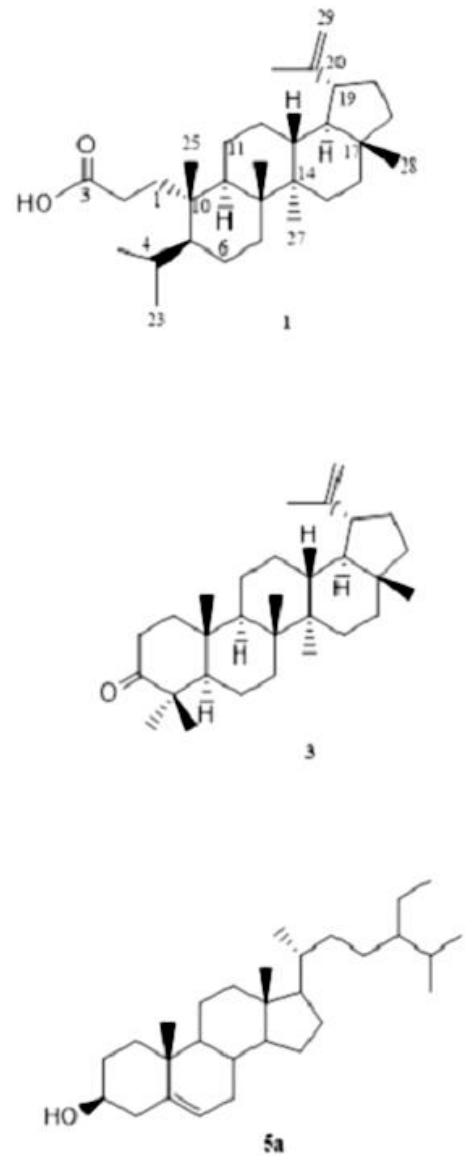

Fig. 1: Chemical structures of dihydrocanaric acid (1), lupeol (2), lupenone (3), 2-hydroxyethyl benzoate (4), $\beta$-sitosterol (5a) and stigmasterol (5b) from $H$. cagayanensis.
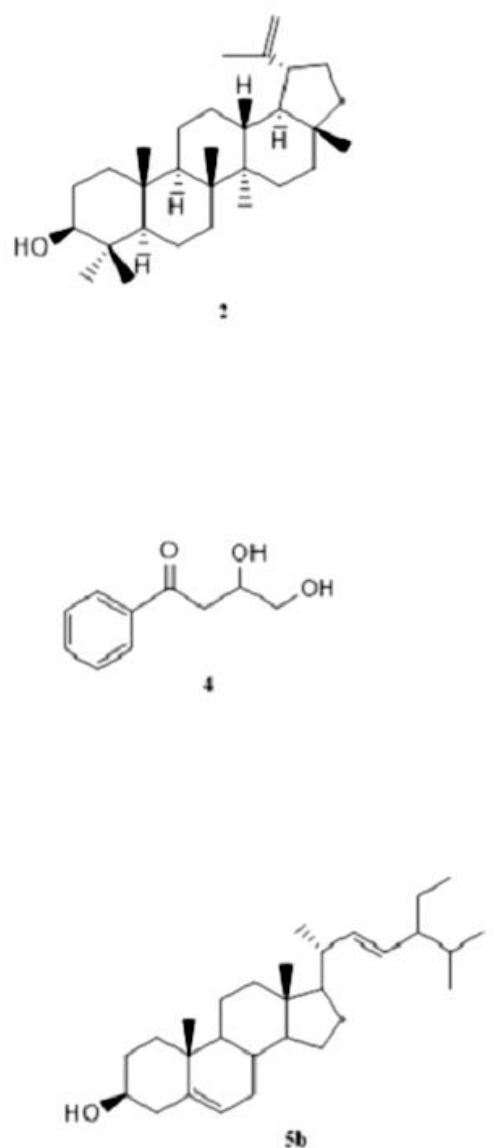

Recently, we reported the isolation of $\beta$-amyrin cinnamate, squalene, $\beta$-sitosterol, a mixture of $\beta$-amyrin, $\alpha$-amyrin and lupeol and saturated hydrocarbons from the leaves; and squalene, taraxerol, lupeol cinnamate, and a mixture of $\beta$-sitosterol and stigmasterol from the stems of $H$. diversifolia (Panajon et al., 2016a). Moreover, the isolation of taraxerol, $\beta$-sitosterol and stigmasterol from $H$. pubicalyx was reported (Panajon et al., 2016b). Lastly, we reported the isolation of taraxerol, taraxeryl acetate, and a mixture of $\alpha$-amyrin acetate and $\beta$-amyrin acetate from H. paziae (Borlagdan et al., 2016).

We report herein the isolation of hydrocanaric acid (1), lupeol (2), lupenone (3), and saturated hydrocarbons from the stems; and 2-hydroxyethyl benzoate (4) and a mixture of $\beta$ sitosterol (5a) and stigmasterol (5b) from the leaves of $H$. cagayanensis. To the best of our knowledge this is the first report on the isolation of 1-5 and hydrocarbons from $H$. cagayanensis.

\section{MATERIALS AND METHODS}

\section{General Experimental Procedure}

${ }^{1} \mathrm{H}(500 \mathrm{MHz})$ and ${ }^{13} \mathrm{C}(125 \mathrm{MHz})$ NMR spectra were acquired in $\mathrm{CDCl}_{3}$ on a $500 \mathrm{MHz}$ Agilent DD2 NMR spectrometer with referencing to solvent signals ( $\delta 7.26$ and $77.0 \mathrm{ppm})$.
Two dimensional NMR experiments recorded included gCOSY, HSQCAD, and gHMBCAD NMR experiments. Column chromatography was performed with silica gel 60 (70-230 mesh). Thin layer chromatography was performed with plastic backed plates coated with silica gel $\mathrm{F}_{254}$ and the plates were visualized by spraying with vanillin $/ \mathrm{H}_{2} \mathrm{SO}_{4}$ solution followed by warming.

\section{Sample Collection}

Stem cuttings were taken from two large specimen plants of $H$. cagayanensis cultivated at the Philippine Nuclear Research Institute Hoya Germplasm Collection under MTA No. 2015-06 dated August 13, 2015 and MTA No. 2016-04 dated June 24, 2016. Accession No. PNRI-H.23 is grown from a cutting that originally came from Quezon province and was subsequently propagated since 1997. It was identified and authenticated by Dr. Simeona V. Siar of the Institute of Plant Breeding, University of the Philippines-Los Baños on February 26, 2008.

\section{General Isolation Procedure}

The air-dried stems $(81.25 \mathrm{~g})$ and leaves $(61.95 \mathrm{~g})$ of $\mathrm{H}$. cagayanensis were ground in a blender, soaked in $\mathrm{CH}_{2} \mathrm{Cl}_{2}$ for three days and then filtered. The filtrates were concentrated under vacuum to afford crude extracts of stems $(4.79 \mathrm{~g})$ and leaves (4.00 
g) which were separately chromatographed by gradient elution with $\mathrm{CH}_{2} \mathrm{Cl}_{2}$, followed by increasing amounts of acetone at $10 \%$ increments by volume as eluents. A glass column 12 inches in height and 0.5 inch internal diameter was used for the fractionation of crude extracts.

Two millilitre fractions were collected. Fractions with spots of the same $\mathrm{R}_{\mathrm{f}}$ values were combined and rechromatographed in appropriate solvent systems until TLC pure isolates were obtained. Rechromatography and final purifications were conducted using Pasteur pipettes as columns. One millilitre fractions were collected.

\section{Isolation of the Chemical Constituents of the Stems}

The crude leaves extract (4.00 g) was chromatographed using increasing proportions of acetone in $\mathrm{CH}_{2} \mathrm{Cl}_{2} \quad(10 \%$ increment) as eluents. The $\mathrm{CH}_{2} \mathrm{Cl}_{2}$ fraction was rechromatographed $(2 \times)$ using petroleum ether to afford hydrocarbons $(5 \mathrm{mg})$ after washing with petroleum ether. The $20 \%$ acetone in $\mathrm{CH}_{2} \mathrm{Cl}_{2}$ fraction was rechromatographed $(3 \times)$ using $5 \%$ EtOAc in petroleum ether to yield 3 (10 $\mathrm{mg}$ ) after washing with petroleum ether.

The $30 \%$ acetone in $\mathrm{CH}_{2} \mathrm{Cl}_{2}$ fraction was rechromatographed $(2 \times)$ using $10 \%$ EtOAc in petroleum ether to yield 2 (3 mg) after washing with petroleum ether. The $40 \%$ acetone in $\mathrm{CH}_{2} \mathrm{Cl}_{2}$ fractions was rechromatographed $(3 \times)$ using $15 \%$ EtOAc in petroleum ether to yield $1(7 \mathrm{mg})$ after washing with petroleum ether.

\section{Isolation of the Chemical Constituents of the Leaves}

The crude stems extract (4.79 g) was chromatographed using increasing proportions of acetone in $\mathrm{CH}_{2} \mathrm{Cl}_{2} \quad(10 \%$ increment) as eluents. The $\mathrm{CH}_{2} \mathrm{Cl}_{2}$ fraction was rechromatographed $(3 \times)$ using $10 \%$ EtOAc in petroleum ether to yield a mixture of $\mathbf{5 a}$ and $\mathbf{5 b}(12 \mathrm{mg})$ after washing with petroleum ether. The $70 \%$ acetone in $\mathrm{CH}_{2} \mathrm{Cl}_{2}$ fraction was rechromatographed using $15 \%$ EtOAc in petroleum ether. Fractions collected from this column were combined and rechromatographed using $\mathrm{CH}_{3} \mathrm{CN}: \mathrm{Et}_{2} \mathrm{O}$ : $\mathrm{CH}_{2} \mathrm{Cl}_{2}(0.5: 0.5: 9, \mathrm{v} / \mathrm{v})$ to afford $4(3 \mathrm{mg})$ after washing with petroleum ether.

\section{Dihydrocanaric acid (1)}

${ }^{1} \mathrm{H}$ NMR $\left(500 \mathrm{MHz}, \mathrm{CDCl}_{3}\right) \delta: 1.58,1.68\left(\mathrm{H}_{2}-1\right), 2.20$ $\left(\mathrm{H}_{2}-2\right), 1.87(\mathrm{H}-4), 0.97(\mathrm{H}-5), 1.36\left(\mathrm{H}_{2}-6\right), 1.33,1.38\left(\mathrm{H}_{2}-7\right)$, 1.44 (H-9), 1.23, $1.36\left(\mathrm{H}_{2}-11\right), 1.05,1.68\left(\mathrm{H}_{2}-12\right), 1.66$ (H-13), 1.05, $1.661 .38\left(\mathrm{H}_{2}-15\right), 1.37,1.47\left(\mathrm{H}_{2}-16\right), 1.37(\mathrm{H}-18), 2.37(\mathrm{H}-$ 19), 1.33, $1.92\left(\mathrm{H}_{2}-21\right), 1.20,1.38\left(\mathrm{H}_{2}-22\right), 0.90(\mathrm{~d}, J=7.0 \mathrm{~Hz}$, $\left.\mathrm{H}_{3}-23\right), 0.79$ (d, $\left.J=6.5 \mathrm{~Hz}, \mathrm{H}_{3}-24\right), 0.81$ (s, H $\left.\mathrm{H}_{3}-25\right), 1.04$ (s, $\mathrm{H}_{3}$ 26), 0.94 (s, $\mathrm{H}_{3}-27$ ), 0.78 ( $\mathrm{s}, \mathrm{H}_{3}-28$ ), 4.57, 4.68 (br s, $\left.\mathrm{H}_{2}-29\right), 1.68$ (br s, $\left.\mathrm{H}_{3}-30\right)$; ${ }^{13} \mathrm{C}$ NMR $\left(125 \mathrm{MHz}, \mathrm{CDCl}_{3}\right) \delta: 32.7$ (C-1), $28.5(\mathrm{C}-$ 2), 180.7 (C-3), 25.4 (C-4), 47.3 (C-5), 18.2 (C-6), 33.0 (C-7), 40.6 (C-8), 40.8 (C-9), 39.9 (C-10), 21.6 (C-11), 25.1 (C-12), 38.1 (C-13), 43.2 (C-14), 27.5 (C-15), 35.5 (C-16), 43.0 (C-17), 48.2 (C-18), 48.0 (C-19), 150.9 (C-20), 29.8 (C-21), 40.0 (C-22), 24.8 (C-23), 18.8 (C-24), 19.6 (C-25), 15.9 (C-26), 14.4 (C-27), 18.0 (C-28), 109.4 (C-29), 19.3 (C-30).

\section{RESULTS AND DISCUSSION}

Silica gel chromatography of the dichloromethane extract of $H$. cagayanensis yielded $\mathbf{1 - 5}$ and hydrocarbons. The structures of 1 and 4 were elucidated by extensive 1D and 2D NMR spectroscopy. The NMR data of $\mathbf{1}$ are similar to those of canaric acid (Lopes et al., 1999), except at C-4 and C-24 where their structures differ. In canaric acid, a double bond is found between C-4 and C-24, while a single bond is present in $\mathbf{1}$. There are also differences in the chemical shifts of the protons and carbons close to C-4 and C-24. The NMR spectra of 2 are in accordance with data reported in the literature for lupeol (Ebajo et al., 2015a), 3 for lupenone (Prakash et al., 2012); 4 for 2-hydroxyethyl benzoate (Sharghi and Sarvari, 2003); 5a for $\beta$-sitosterol (Ebajo et al., 2015a), 5b for stigmasterol (Ebajo et al., 2015a) and hydrocarbons (Ebajo et al., 2015c).

Although there is no reported biological acitivity for $H$. cagayanensis, the compounds (1-3 and $\mathbf{5 a - 5 b})$ isolated from the plant were reported to possess diverse activities.

An earlier study reported that dihydrocanaric acid (1) exhibited growth inhibitory activity against both HeLa and SW480 cells (Sadhu et al., 2008). It was also reported as a powerful antioxidant (Ghosh et al., 2010).

Lupeol (2) exhibited antiurolithiatic and diuretic activity (Vidya et al., 2002). It prevented the formation of vesical calculi and reduced the size of the preformed stones in rats (Anand et al., 1994). It also showed antifungal activity against Fusarium oxysporum and Penicillium notatum (Manzano et al., 2013). Lupeol significantly reduced the 451Lu tumor growth in athymic nude mice (Saleem et al., 2008), inhibited the proliferation of MDA-MB-231 human breast cancer cells in a dose dependent manner (Lambertini et al., 2005), and induced growth inhibition and apoptosis in hepatocellular carcinoma SMMC7721 cells by down-regulation of the death receptor 3 (DR3) expression (Zhang et al., 2009). Lupeol and lupeol acetate (2a) have shown hypotensive activity (Saleem et al., 2003), while 1a also exhibited antidyslipidemic activity in hamster at $100 \mathrm{mg} / \mathrm{Kg}$ body weight (Reddy et al., 2009). It exhibited potent anti-inflammatory activity in an allergic airway inflammation model by a significant reduction in eosinophils infiltration and in Th2-associated cytokines levels that trigger the immune responses in asthma (Vasconcelos et al., 2008). A review on the biological activities of lupeol has been provided (Gallo and Sarachine, 2009).

Lupenone (3) inhibits adipocyte differentiation by suppressing PPAR $\gamma$ and $\mathrm{C} / \mathrm{EBP} \alpha$ protein levels (Ahn and $\mathrm{Oh}$, 2013). It also increases the tyrosinase enzyme expression via mitogen-activated protein kinase phosphorylated extracellular signal regulated kinases 1 and 2 phosphorylation inhibition which results to stimulation of melanogenesis. This suggests that lupenone could be a possible treatment for hypopigmentation (Villareal et al., 2013). $\beta$-Sitosterol (5a) has been reported to have growth inhibitory effects on human breast MCF-7 and MDA-MB231 adenocarcinoma cells (Awad et al. 2007). It was shown to be effective for the treatment of benign prostatic hyperplasia 
(Jayaprakasya et al., 2007). It was observed to attenuate $\beta$-catenin and PCNA expression, as well as quench free radical in vitro, making it a potential anticancer drug for colon carcinogenesis (Baskar, et al., 2010), and inhibit the expression of NPC1L1 in the enterocytes to reduce intestinal cholesterol uptake (Jesch et al., 2009). It was also reported to induce apoptosis mediated by the activation of ERK and the downregulation of Akt in MCA-102 murine fibrosarcoma cells (Moon et al., 2007).

On the other hand, stigmasterol (5b) shows therapeutic efficacy against Ehrlich ascites carcinoma in mice while conferring protection against cancer induced altered physiological conditions (Ghosh et al., 2011). It has been reported to lower plasma cholesterol levels, inhibit intestinal cholesterol and plant sterol absorption, and suppress hepatic cholesterol and classic bile acid synthesis in Winstar and WKY rats (Batta et al., 2006). In other studies, stigmasterol showed cytostatic activity against Hep2 and McCoy cells (Gomez et al., 2001), markedly inhibited tumour promotion in two stage carcinogenesis experiments (Kasahara et al., 1994), and exhibited antimutagenic (Lim et al., 2005), topical anti-inflammatory (Garcia et al., 1999), antiosteoarthritic (Gabay et al., 2010) and antioxidant (Panda et al., 2009) activities.

\section{CONCLUSION}

H. cagayanensis shares similar chemical characteristics with other members of the Philippine native hoyas: $H$. mindorensis (Ebajo et al., 2014), H. multifora (Ebajo et al., 2015a), and $H$. diversifolia (Panajon et al., 2016a) which yielded lupeol (2); $H$. mindorensis (Ebajo et al., 2014) which contained lupenone (3); H. mindorensis (Ebajo et al., 2014), H. multifora (Ebajo et al., 2015a), H. wayetii (Ebajo et al., 2015b), H. buotii (Ebajo et al., 2015c), H. diversifolia (Panajon et al., 2016a), and H. pubicalyx (Panajon et al., 2016b) which afforded $\beta$-sitosterol (5a); $H$. multifora (Ebajo et al., 2015a), H. wayetii (Ebajo et al., 2015b), H. buotii (Ebajo et al., 2015c), and H. pubicalyx (Panajon et al., 2016b) which contained stigmasterol (5b); and H. buotii (Ebajo et al., 2015c) and $H$. diversifolia (Panajon et al., 2016a) which yielded saturated hydrocarbons. This is the first report on the isolation of dihydrocanaric acid (1) and 2-hydroxyethyl benzoate (4) from Philippine native hoyas.

\section{ACKNOWLEDGEMENT}

Financial support and sponsorship: A research grant from the De La Salle University Science Foundation through the University Research Coordination Office is gratefully acknowledged. .

Conflict of Interests: The authors' declare no conflict of interest.

\section{REFERENCES}

Ahn, EK, Oh JS. Lupenone isolated from Adenophora triphylla var. japonica extract inhibits adipogenic differentiation through the downregulation of PPAR $\gamma$ in 3T3-L1 cells. Phytother. Res., 2013; 5:761766.
Anand R, Patnaik GK, Kulshreshtha DK, Dhawan N. Antiurolithiatic activity of lupeol, the active constituent of Crateva nuriala. Phytother Res 1994; 8 (7):417-421.

Aurigue FB. 2013. A Collection of Philippine Hoyas and Their Culture, Philippine Council for Agriculture, Aquatic and Natural Resources Research and Development (PCAARRD). Department of Science and Technology (DOST). 195 pages.

Awad AB, Chinnman M, Fink CS, Bradford PG. beta-Sitosterol activates Fas signaling in human breast cancer cells. Phytomedicine 2007; 14:747-754.

Baskar AA, Ignacimuthu S, Paulraj G, Numair K. Chemopreventive potential of $\beta$-Sitosterol in experimental colon cancer model - an In vitro and In vivo study. BMC Comp Alt Med 2010; 10, 24.

Batta AK, Xu G, Honda A, Miyazaki T, Salen G. Stigmasterol reduces plasma cholesterol levels and inhibits hepatic synthesis and intestinal absorption in the rat. Metabolism 2006; 55(3):292-299.

Borlagdan M, Aurigue F, van Altena I, Ragasa CY. Triterpenes from Hoya paziae Kloppenb. Phcog J 2016; 8(5):487-489.

Ebajo Jr VD, C-C Shen, Ragasa CY. Triterpenes and sterol from Hoya mindorensis. Der Pharma Chemica 2014; 6(4):321-325.

Ebajo Jr VD, Shen C-C, Ragasa CY. Terpenoids and sterols from Hoya multiflora Blume. J Appl Pharm Sci 2015a; 5(3):33-39.

Ebajo Jr VD, Aurigue FB, Brkljača R, Urban S, Ragasa CY. Chemical constituents of Hoya wayetii Kloppenb. Int J Pharmacog Phytochem Res 2015b; 7(5):1041-1045.

Ebajo Jr VD, Brkljača R, Urban S, Ragasa CY. Chemical constituents of Hoya buotii Kloppenb. J Appl Pharm Sci 2015c; 5(11):6972.

Gallo MBC, Sarachine MJ. Biological activities of lupeol. Intl J Biomed Pharm Sci 2009; 3 (1):46-66.

Gabay O, Sanchez C, Salvat C, Chevy F, Breton M, Nourissat G. Stigmasterol: a phytosterol with potential anti-osteoarthritic properties. Osteoarthr Cartil 2010; 18(1):106-116.

García MD, Sáenz MT, Gómez MA, Fernández MA. Topical antiinflammatory activity of phytosterols isolated from Eryngium foetidum on chronic and acute inflammation models. Phytother Res 1999; 13(1):7880 .

Ghosh T, Maity TK, Singh J. Evaluation of antitumor activity of stigmasterol, a constituent isolated from Bacopa monnieri Linn aerial parts against Ehrlich Ascites Carcinoma in mice. Orient Pharm Exp Med 2011; 11:41-49.

Ghosh A, Sarkar A, Mitra P, Banerji A, Banerji J et al. Crystal structure and DFT calculations of 3,4-seco-lup-20(29)-en-3-oic acid isolated from Wrightia tinctoria: Stacking of supramolecular dimmers in the crystal lattice. Journal of Molecular Structure 2010; 980:7-12.

Gómez MA, García MD, Sáenz MT. Cytostatic activity of Achillea ageratum L. Phytother Res 2001; 15(7):633-634.

Jayaprakasha GK, Mandadi KK, Poulose SM, Jadegoud Y, Gowda GA, Patil BS. Inhibition of colon cancer cell growth and antioxidant activity of bioactive compounds from Poncirus trifoliata (L.) Raf. Bioorg Med Chem 2007; 4923-4932.

Jesch ED, Seo JM, Carr TP, Lee JY. Sitosterol reduces messenger RNA and protein expression levels of Niemann-Pick C1-like 1 in FHs 74 Int cells. Nutr Res 2009; 29(12):859-66.

Kasahara Y, Kumaki K, Katagiri S, Yasukawa K, Yamanouchi S, Takido M. Carthami flos extract and its component, stigmasterol, inhibit tumour promotion in mouse skin two-stage carcinogenesis. Phytother Res 1994; 8(6):327-331.

Lambertini E, Lampronti I, Penolazzi L, Khan MTH, Ather A, Giorgi G, Gambari R, Piva R. Expression of estrogen receptor gene in breast cancer cells treated with transcription factor decoy is modulated by Bangladeshi natural plant extracts. Oncol Res 2005; 14: 69-79.

Lim, J-C, Park, JH, Budesinsky, M, Kasal, A, Han, Y-H, Koo, B-S, Lee, S-I, Lee, D-U. Antimutagenic constituents from the thorns of Gleditsia sinensis Chem Pharm Bull 2005; 53(5):561-564.

Lopes MN, Mazza FC, Young MCM, Bolzania VdS. Complete assignments of ${ }^{1} \mathrm{H}$ and ${ }^{13} \mathrm{C}$-NMR spectra of the 3,4-seco-triterpene canaric acid isolated from Rudgea jasminoides. J Braz Chem Soc 1999; 10(3):237-240. 
Manzano PI, Miranda M, Abreu-Payrol J, Silva M, Sterner O,Peralta EL. Pentacyclic triterpenoids with antimicrobial activity from the leaves of Vernonanthura patens (Asteraceae). Emir J Food Agric 2013; 25(7):539-543.

Moon DO, Kyeong-Jun L, Yung HC, Gi-Young K. $\beta$-Sitosterolinduced-apoptosis is mediated by the activation of ERK and the downregulation of Akt in MCA-102 murine fibrosarcoma cells. Int Immunopharmacol Int Immunopharmacol 2007; 7:1044-1053.

Panda S, Jafri M, Kar A, Meheta BK. Thyroid inhibitory, antiperoxidative and hypoglycemic effects of stigmasterol isolated from Butea monosperma. Fitoter 2009; 80(2):123-126.

Panajon NM, Aurigue FB, Shen C-C, Ragasa CY. Triterpenes and sterols from Hoya diversifolia Blume. J Appl Pharm Sci 2016a; 6(6):79-82

Panajon NM, Aurigue FB, Shen C-C, Ragasa CY. Triterpenes and sterols from Hoya pubicalyx. Der Pharmacia Lettre 2016b; 8(13):270273.

Prakash CVS, Prakash I. Isolation and structural characterization of lupane triterpenes from Polypodium Vulgare. Res $\mathbf{J}$ Pharm Sci 2012; 1(1):23-27.

Reddy KP, Singh AB, Puri A, Srivastava AK, Narender T. Synthesis of novel triterpenoid (lupeol) derivatives and their in vivo antihyperglycemic and antidyslipidemic activity. Bioorg Med Chem Lett 2009; 19:4463-4466.

Sadhu SK, Khatun A, Ohtsuki T, Ishibashi M. Constituents from Hoya parasitica and their cell growth inhibitory activity. Planta Med 2008; 74(7):760-763..

Saleem M, Maddodi N, Zaid MA, Khan N, Hafeez B, Asim M, Suh Y, Yun J, Setaluri V, Mukhtar H. Lupeol inhibits growth of highly aggressive human metastatic melanoma cells in vitro and in vivo by inducing apoptosis. Cancer Therapy: Preclinical 2008; 14:2119-2127.
Sharghi H, Sarvari MH. Highly selective methodology for the direct ccnversion of aromatic aldehydes to glycol monoesters. J Org Chem 2003; 68:4096-4099.

Vasconcelos JF, Teixeira MM, Barbosa-Filho JM, Lúcio ASSC, Almeida JRGS, Queiroz LP, Ribeiro-dos-Santos R, Soares MBP. The triterpenoid lupeol attenuates allergic airway inflammation in a murine model. Intl Immunopharmacol 2008; 8:1216-1221.

Vidya L, Leni M, Varalakshmi P. Evaluation of the effect of triterpenes on urinary risk factors of stone formation in pyridoxine hyperoxaluric rats. Phytother Res 2002; 16 (6):514-518.

Villareal MO, Han J, Matsuyama M, Sekii Y, Smaoui A, Shigemori H, Isoda H. Lupenone from Erica multiflora leaf extract stimulates melanogenesis in B16 murine melanoma cells through the inhibition of ERK1/2 activation. Planta Med 2013; 79(3-4):236-243.

Zhang L, Zhang Y, Zhang L, Yang X, Lv Z. Lupeol, a dietary triterpene, inhibited growth, and induced apoptosis through downregulation of DR3 in SMMC7721 cells. Cancer Investigation 2009; 27:163-170

\section{How to cite this article:}

Ragasa C, Borlagdan M, Aurigue F, Brkljaca R, Urban S. Chemical Constituents of Hoya cagayanensis C. M. Burton. J App Pharm Sci, 2017; 7 (05): 061-065. 